\title{
Chemical composition and nutritive value of South African sorghum varieties as feed for broiler chickens
}

\author{
M. Mabelebele ${ }^{1,2 \#}$, M. Siwela ${ }^{3}$, R.M. Gous ${ }^{3}$ \& P.A. lji $^{1}$ \\ ${ }^{1}$ University of New England, School of Rural and Environmental Sciences, Armidale, \\ New South Wales, Australia \\ ${ }^{2}$ University of Limpopo, School of Agricultural and Environmental Sciences, Polokwane, South Africa \\ ${ }^{3}$ University of KwaZulu-Natal, School of Agricultural, Earth and Environmental Sciences, Scottsville, \\ Pietermaritzburg, South Africa
}

(Received 12 January 2014; Accepted 18 April 2015; First published online 20 July 2015)

Copyright resides with the authors in terms of the Creative Commons Attribution 2.5 South African Licence. See: http://creativecommons.org/licenses/by/2.5/za

Condition of use: The user may copy, distribute, transmit and adapt the work, but must recognise the authors and the South African Journal of Animal Science.

\begin{abstract}
Sorghum (Sorghum bicolor (L.) Moench) is the fifth most important grain crop after wheat, rice, maize and barley. It is cultivated for food and feed in America, Asia, Australia and Africa. Newly developed sorghum varieties should be evaluated for their suitability as food and feed. The physical characteristics and proximate composition, total phenolic content, mineral content, amino acid profile and digestibility, and true metabolizable energy of four sorghum varieties were studied. The condensed tannin sorghum varieties PAN8625 and NS5511 had higher total phenolic content and antioxidant activity than the non-tannin varieties PAN8816 and PAN8906. Crude protein content diverged narrowly across the varieties, ranging from 81.2 to $95.4 \mathrm{~g} / \mathrm{kg} \mathrm{DM}$. Starch and gross energy contents also differed, though varieties that were used had similar total and individual mineral contents. The threonine, leucine, phenylalanine, valine, proline and alanine contents of PAN8625 and PAN8906 were higher than those of NS5511 and PAN8816, which had similar contents. Amino acid digestibility and metabolizable energy of the tannin varieties were generally lower than those of the non-tannin ones. These results indicate that chemical and nutrient composition of sorghum varieties should be considered when selecting for broiler chicken feeding.
\end{abstract}

Keywords: Amino acid profile, minerals, tannin sorghum, total phenolics

\# Corresponding author: mabelebelem@gmail.com

\section{Introduction}

The use of maize as the main energy source in poultry diets is subjected to the age-old competition between animals and humans. The grain is increasingly being used to produce ethanol, particularly in North America. Many areas in the world are not self-sufficient in grain production to meet human and animal needs and have depended on imports from North America. Maize grain prices have therefore remained high and will probably increase in future. Therefore, alternative, accessible and cost-effective ingredients are needed that can provide the same nutrients as maize. Sorghum (Sorghum bicolor) has been identified as a suitable replacement for maize (Medugu et al., 2010). It is abundant in most parts of Africa and Asia, and is among the main cereal crops that are used as food and feed. The adaptive agronomic characteristics of sorghum make it suitable for cultivation in different environmental conditions.

Sorghum varieties have been used for many years for poultry and human consumption, especially in Africa and Asia, and have been shown to vary in physical and chemical characteristics (Neucere \& Sumrell, 1980; Sedghi et al., 2011). While some authors have reported anti-nutritional factors in sorghum grain that have adverse effects on the utilization of sorghum protein and metabolizable energy by poultry, such as tannins (Gous et al., 1982; Boren \& Waniska, 1992), others have stated that these factors do not always reduce the performance of poultry (Nyachoti et al., 1997). This indicates the possibility of other factors contributing to the poor feeding value of certain sorghum varieties. In human beings, sorghum that is consumed as refined or whole grain has proved to have potential health benefits (Mabelebele \& lji, 2013). The nutritive values of several South African sorghum varieties in broiler diets have not yet been reported. Therefore, the objective of the current study was to determine the physical characteristics and nutritive value of four sorghum varieties as potential alternative feed ingredients for poultry. 


\section{Materials and Methods}

Four commercial hybrid sorghum grain varieties grown in a controlled field trial at Pannar Research Services (Pty) Ltd, Klerksdorp, South Africa, were used in this study. The mean temperatures around the area are above $29^{\circ} \mathrm{C}$ in summer and below $21^{\circ} \mathrm{C}$ in winter. It lies at latitude $26.55^{\prime} 8 \mathrm{~S}$ and longitude $26.40^{\prime} 0$ $\mathrm{E}$. These varieties were grown in the 2010 - 2011 season under dry land conditions that receive a mean annual rainfall of less than $482 \mathrm{~mm}$.

The varieties that were selected for their outstanding yield performance, agronomic characteristics, preference by farmers and tannin contents were Pannar seed hybrids (PAN8625, PAN8816, PAN8906) and a national seeds hybrid (NS5511). The grains were field dried and harvested at less than $14 \%$ moisture content. Five kilograms of each variety were cleaned to remove broken and foreign materials prior to laboratory analysis.

The thousand-kernel weight (TKW) was determined by weighing 1000 sound kernels as a representative sample. The colour of the grain was observed visually and HunterLab L (lightness), a (redness) and b (green) colour values were measured with a Konica Minolta CR-400 c camera (Konica Minolta, Sakai, Osaka, Japan). A total of 20 sound kernels of each variety were cut in half with a blade, and kernel texture was assessed for the proportion of corneous and floury endosperms. The dissected kernels were viewed with a Leica M216 stereomicroscope equipped with a Leica DF C450 digital camera (Leica Microsystems, Heerbrugg, Switzerland). The outer layer (pericarp) of kernels of the four sorghum varieties was scratched with a scalpel and viewed under the light microscope to check for the presence or absence of a pigmented testa. The bleach test was used to detect sorghum grains with a pigmented testa (Taylor, 2001). The total phenolic concentration of milled grain of each sorghum variety was determined with the Folin-Ciocalteu assay described by Singleton \& Rossi (1965). The vanillin-HCL assay of Price et al. (1978) was used to measure the condensed tannin content. Absorbance was read at $500 \mathrm{~nm}$ and catechin was used as a standard.

Proximate analysis for moisture, ash, crude protein $(\mathrm{N} \times 6.25)$, fat and starch was carried out according to the standard methods of AOAC (2005). Ground samples of each variety were oven-dried and weighed. The sample, in a crucible, was ashed in a muffle furnace at $550^{\circ} \mathrm{C}$ for 6 hours. The ash was aciddigested by adding $1 \mathrm{~mL} 55 \%(\mathrm{v} / \mathrm{v}) \mathrm{HNO}_{3}$. After cooling, calcium, magnesium, manganese, zinc, iron, sodium, potassium, copper, sulphur and phosphorus concentrations were determined by AOAC method 6.1.2 (2005) using inductively coupled plasma spectroscopy. Neutral detergent fibre (NDF) and acid detergent fibre (ADF) were established according to the methods of Van Soest et al. (1991). The gross energy contents of the milled samples and excreta were determined with adiabatic bomb calorimetry (Gallenkamp, Autobomb, London, UK).

The modified intubation assay of McNab \& Blair (1988) was used to determine the apparent metabolizable energy (AME) and true metabolizable energy (TME) contents of the cultivars. A total of 48 adult male laying-type birds were used in the evaluation, having been fasted for $48 \mathrm{~h}$ prior to being fed the samples. The roosters were kept in battery cages and were assigned to four treatments (sorghum varieties), replicated three times with four birds per replicate.

The birds were given $50 \mathrm{~g}$ glucose dissolved in $50 \mathrm{~mL}$ water by intubation after $24 \mathrm{~h}$ fasting to ensure an adequate energy supply during the fasting period. Twelve birds per variety were then given $50 \mathrm{~g}$ milled sorghum by intubation. Excreta were collected in trays beneath each cage over the following $48 \mathrm{~h}$, dried at $70^{\circ} \mathrm{C}$ in an oven for $48 \mathrm{~h}$ and then weighed. The milled sorghum and excreta samples were hydrolysed with $6 \mathrm{~N} \mathrm{HCl}$ at $110{ }^{\circ} \mathrm{C}$ for $24 \mathrm{~h}$ (AOAC, 2005) and analysed for amino acids using Shimadzu HLPC reversephase high-pressure liquid chromatography (Shimadzu LC-10 AD, Shimadzu Corporation, Kyoto, Japan) with Shimmpack amino-Na-type column, $10 \mathrm{~cm} \times 6.0 \mathrm{~mm}$ (Shimadzu Corporation). Samples were post column derivatized with o-phaldialdehde and detected with the Shimadzu RF-10A fluorescent detector (Shimadzu Corporation). Data were recorded and integrated using a Chromatopack CR7-A integrator model (Shimadzu Corporation). AME, TME and amino acid digestibility values were calculated with the following formulae with appropriate corrections for differences in dry matter (DM) content:

1. $\quad \operatorname{AME}(M J / k g)=\left[\left(\right.\right.$ feed intake $\left.\times G_{\text {diet }}\right)-\left(\right.$ excreta output $\left.\left.\times G E_{\text {excreta }}\right)\right] /$ feed intake

2. $\operatorname{TME}(\mathrm{MJ} / \mathrm{kg})=\left[\left(\right.\right.$ feed intake $\left.\times \mathrm{GE}_{\text {diet }}\right)-($ excreta energy - excreta energy of the fasted bird $\left.)\right] /$ feed intake

3. Amino acid digestibility $=\left[\mathrm{AA}_{\text {consumed }}-\mathrm{AA}_{\text {excreted }} / \mathrm{AA}_{\text {consumed }}\right] \times 100$

Samples were collected in triplicate from each variety to determine the chemical composition and nutritive value of the grains. Data were analysed using a one-way analysis of variance of SAS statistical analysis software (SAS, 2008). When ANOVA indicated a significant $P$-value, means were separated using 
Duncan's multiple range test. Pearson's correlation coefficient was used to decide whether there were linear relationships between Hunter $L A B$, texture, antioxidant activity, total phenolic and condensed tannins.

\section{Results and Discussion}

The kernel characteristics of the grains are presented in Table 1. The TKW ranged from 33 to $28 \mathrm{~g}$, with PAN8906 having the highest $(P<0.05)$ TKW. The visual kernel colour of all the grains was brown, except for PAN8906, which was red. There were significant $(P<0.05)$ differences in HunterLab values among the varieties. The HunterLab values ranged from 41.6 (lightest) to 38.2 (darkest). PAN8816 was harder $(P<0.05)$ than other varieties (Table 1). PAN8625 and NS5511 had pigmented testa, whereas this was absent in the other two varieties (Table 2). The varieties that had pigmented testa tested positive for the bleach reaction, while the varieties without a pigmented testa tested negative. Thus, in the current study, the bleach reaction and the scratch test results indicate that PAN8625 and NS5511 contained condensed tannins, while varieties PAN8816 and PAN8906 were tannin-free. Indeed, PAN8625 and NS5511 had higher condensed tannin concentrations than PAN8816 and PAN8906 (Table 2). The tannin varieties in the present study were reported to have higher total phenolic concentrations than the non-tannin varieties. These results are similar to the reports of Awika et al. (2005), Dykes et al. (2005) and Chiremba et al. (2009).

Table 1 Kernel characteristics of four sorghum varieties

\begin{tabular}{|c|c|c|c|c|c|c|c|}
\hline \multirow{2}{*}{ Sorghum } & \multirow{2}{*}{ TKW } & \multirow{2}{*}{ VKC } & \multirow{2}{*}{ MGW } & \multirow{2}{*}{ Texture } & \multicolumn{3}{|c|}{ Kernel colour (Hunter) ${ }^{1}$} \\
\hline & & & & & $\mathbf{L}$ & $\mathbf{a}$ & b \\
\hline PAN8625 & $28^{c}$ & Brown & $8.7^{\mathrm{a}}$ & $2^{a}$ & $40.0^{\mathrm{ab}}$ & $15.8^{\mathrm{a}}$ & $23.0^{\mathrm{a}}$ \\
\hline PAN8816 & $31^{\mathrm{ab}}$ & Brown & $8.6^{\mathrm{b}}$ & $1^{\mathrm{b}}$ & $41.6^{\mathrm{a}}$ & $16.0^{\mathrm{a}}$ & $23.2^{\mathrm{a}}$ \\
\hline NS5511 & $30^{b}$ & Brown & $8.7^{\mathrm{a}}$ & $2^{\mathrm{a}}$ & $38.2^{b}$ & $15.7^{\mathrm{a}}$ & $22.6^{a}$ \\
\hline PAN8906 & $33^{a}$ & Dark red & $8.4^{\mathrm{c}}$ & $2^{a}$ & $38.6^{\mathrm{b}}$ & $12.5^{b}$ & $16.5^{\mathrm{b}}$ \\
\hline $\begin{array}{l}\text { TKW: } 1000 \\
\text { VKC: visual } \\
\text { MGW: mois } \\
{ }^{1} \text { HunterLAB } \\
\text { a,b,c,d } \text { Means }\end{array}$ & $\begin{array}{l}\text { weigh } \\
\text { colou } \\
\text { whole } \\
\text { : light } \\
\text { same }\end{array}$ & $\begin{array}{l}\text { : kernel } \\
\text { o); } \\
\text { redness, } \\
\text { with diffe }\end{array}$ & $\begin{array}{l}\text { colo } \\
\text { scrip }\end{array}$ & . & & & \\
\hline
\end{tabular}

Table 2 Phenolic concentration and antioxidant activity of grain of four sorghum varieties

\begin{tabular}{llrllr}
\hline Sorghum & ST & BR & TP & CT & AOA \\
\hline PAN8625 & $(+)$ & 80 & $0.1^{\mathrm{a}}$ & $2.0^{\mathrm{b}}$ & $-50.0^{\mathrm{b}}$ \\
PAN8816 & $(-)$ & 0 & $0.0^{\mathrm{b}}$ & $0.1^{\mathrm{d}}$ & $23.8^{\mathrm{d}}$ \\
NS5511 & $(+)$ & 92 & $0.1^{\mathrm{a}}$ & $3.2^{\mathrm{a}}$ & $-144.7^{\mathrm{a}}$ \\
PAN8906 & $(-)$ & 0 & $0.0^{\mathrm{b}}$ & $0.2^{\mathrm{c}}$ & $51.8^{\mathrm{c}}$ \\
\hline
\end{tabular}

ST: scratch test: (-) indicates the absence of pigmented testa; (+) indicates the presence of pigmented testa;

BR: bleach reaction (\% of kernel staining black);

TP: total phenols ( $\mathrm{mg}$ of gallic acid equivalent/100 mg);

$\mathrm{CT}$ : condensed tannins concentration (mg of catechin equivalent/100 mg);

AOA: antioxidant activity (DPPH inhibition \%).

$a, b, c, d$ Means in the same column with different superscripts are significantly different $(P<0.05)$.

The correlation analysis suggests that the condensed tannins in the tannin varieties PAN8625 and NS5511 contributed to their higher antioxidant activity relative to the non-tannin varieties PAN8816 and PAN8906 (Table 3). Many authors working with sorghum varieties containing different phenolic types have reported similar results and reached similar conclusions (Awika et al., 2003; 2005; Dykes et al., 2005; Chiremba et al., 2009). 
Table 3 Pearson correlation coefficient ( $r$ ) among kernel characteristics, phenolic content and antioxidant activity of four sorghum varieties

\begin{tabular}{lccccccc}
\hline & $\mathbf{L}^{\mathbf{1}}$ & $\mathbf{A}^{\mathbf{1}}$ & $\mathbf{B}^{\mathbf{1}}$ & Texture & TP & $\mathbf{C T}$ & $\mathbf{A O A}$ \\
\hline $\mathrm{L}$ & 1.0 & & & & & & \\
$\mathrm{a}$ & 0.2 & 1.0 & & & & & \\
$\mathrm{~b}$ & 0.4 & $0.9^{\star \star \star}$ & 1.0 & & & & \\
Texture & -0.4 & -0.2 & -0.2 & 1.0 & & & \\
TP & -0.4 & 0.4 & 0.4 & 0.1 & 1.0 & & \\
CT & -0.4 & 0.4 & 0.4 & 0.2 & $0.9^{\star \star \star}$ & 1.0 & \\
AOA & 0.3 & $-0.5^{\star \star}$ & -0.5 & -0.1 & $-0.9^{\star \star \star}$ & $-0.9^{\star \star \star}$ & 1.0 \\
\hline
\end{tabular}

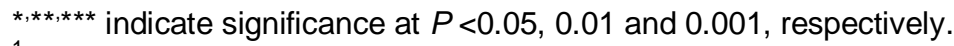

${ }^{1}$ HunterLab test: L: lightness, a: redness, b: green colour value;

TP: total phenols ( $\mathrm{mg}$ of gallic acid equivalent/100 $\mathrm{mg}$ );

$\mathrm{CT}$ : condensed tannins concentration ( $\mathrm{mg}$ of catechin equivalent/100 mg);

AOA: antioxidant activity (DPPH inhibition \%).

The proximate composition of the four sorghum varieties is presented in Table 4 . The ash value of PAN8816 was lower $(P<0.05)$ than values for PAN8625, NS5511 and PAN8906. Fat content varied among the varieties, ranging from 27 to $37 \mathrm{~g} / \mathrm{kg} \mathrm{DM}$. These fat contents were slightly lower than the sorghum cultivars evaluated by Gassem \& Osman (2003), which ranged from 35.8 to $44.7 \mathrm{~g} / \mathrm{kg} \mathrm{DM}$, although they were similar to those reported by Basahy (1995) and Abdel-Rahman (2000). The ADFN and NDFN contents diverged, with ADFN varying to a greater extent (47 to $82 \mathrm{~g} / \mathrm{kg} \mathrm{DM}$ ) than the NDFN contents (117 to $148 \mathrm{~g} / \mathrm{kg}$ DM). The tannin varieties had higher ADFN and NDFN concentrations than the non-tannin ones (76 and 143 vs. 53 and $118 \mathrm{~g} / \mathrm{kg} \mathrm{DM}$, respectively). The ADFN and NDFN concentrations of the tannin sorghum varieties evaluated by Parnian et al. (2013) were considerably higher (139 and $224 \mathrm{~g} / \mathrm{kg} \mathrm{DM}$, respectively) than those measured in the current study. The contribution of polyphenols to the lignin fraction of the dietary fibre is usually responsible for the higher values of dietary fibre in the tannin varieties.

Table 4 Proximate composition ( $\mathrm{g} / \mathrm{kg}$ ) of grains of four sorghum varieties (DM basis)

\begin{tabular}{|c|c|c|c|c|c|c|c|}
\hline Sorghum & Moist & Ash & Fat & ADFN & NDFN & $\mathrm{CP}$ & Starch \\
\hline PAN8625 & $63.4^{\mathrm{a}}$ & $15^{a}$ & $27.1^{d}$ & $81.9^{a}$ & $138^{b}$ & $95.3^{a}$ & $547^{\mathrm{a}}$ \\
\hline PAN8816 & $58.3^{\mathrm{b}}$ & $13^{b}$ & $31.3^{\mathrm{b}}$ & $47.4^{d}$ & $118^{\mathrm{c}}$ & $81.1^{\mathrm{b}}$ & $503^{c}$ \\
\hline NS5511 & $49.3^{d}$ & $15^{a}$ & $37.3^{a}$ & $71.4^{\mathrm{b}}$ & $148^{a}$ & $84.4^{\mathrm{b}}$ & $532^{\mathrm{ab}}$ \\
\hline PAN8906 & $49.8^{c}$ & $15^{a}$ & $29.1^{\mathrm{c}}$ & $59.6^{c}$ & $117^{\mathrm{C}}$ & $95.4^{\mathrm{a}}$ & $513^{b c}$ \\
\hline SEM & 0 & 0.176 & 0.404 & 1.511 & 1.410 & 1.147 & 6.796 \\
\hline \multicolumn{8}{|c|}{$\begin{array}{l}\text { Moist: moisture content of sample; } \\
\text { ADFN: acid detergent fibre corrected for nitrogen; } \\
\text { NDFN: neutral detergent fibre corrected for nitrogen; } \\
\text { CP: crude protein. } \\
\text { a,b,c,d Means in the same column with different supersc }\end{array}$} \\
\hline
\end{tabular}

The crude protein level ranged from 81 to $95 \mathrm{~g} / \mathrm{kg} D$, averaging $89 \mathrm{~g} / \mathrm{kg} D \mathrm{DM}$. These values were similar to those of Gualtleri \& Rapaccini (1990), Rooney \& Serna-Saldivar (2000) and Issa (2009) who reported crude protein contents of sorghum ranging from 60 to $100 \mathrm{~g} / \mathrm{kg} \mathrm{DM}$. The starch content varied narrowly between 503 and $547 \mathrm{~g} / \mathrm{kg}$ DM. The highest starch content $(542 \mathrm{~g} / \mathrm{kg} \mathrm{DM})$ was observed in PAN8625. This value was lower than the average starch content reported for sorghum generally, which ranges from 560 to $730 \mathrm{~g} / \mathrm{kg}$ DM (Geleta et al., 2005; Ragaee et al., 2006; Boudries et al., 2009). The 
variations in chemical and proximate composition could be owing to differences in genotype and growing conditions such as geographical and seasonal variations, climatic conditions and soil characteristics.

Table 5 Mineral concentrations of grains of four sorghum varieties (mg/kg DM)

\begin{tabular}{|c|c|c|c|c|c|}
\hline & \multicolumn{4}{|c|}{ Sorghum variety } & \multirow{2}{*}{ SEM } \\
\hline & PAN8625 & PAN8816 & NS5511 & PAN8906 & \\
\hline \multicolumn{6}{|l|}{ Macro minerals } \\
\hline Calcium & $121.3^{\mathrm{a}}$ & $100.1^{b}$ & $121.1^{\mathrm{a}}$ & $100.2^{b}$ & 0.005 \\
\hline Magnesium & $1440^{a}$ & $1130^{b}$ & $1212^{b}$ & $1401^{a}$ & 0.002 \\
\hline Potassium & $3096^{b}$ & $2751^{c}$ & $3524^{\mathrm{a}}$ & $2994^{b}$ & 0.005 \\
\hline Sodium & $20^{b}$ & $20^{b}$ & $30^{\mathrm{ab}}$ & $40^{\mathrm{a}}$ & 0.004 \\
\hline Sulphur & $910^{\mathrm{ab}}$ & $870^{a b}$ & $812^{b}$ & $957^{\mathrm{a}}$ & 0.003 \\
\hline Phosphorus & $3055^{b}$ & $2210^{d}$ & $2454^{c}$ & $3327^{\mathrm{a}}$ & 0.005 \\
\hline \multicolumn{6}{|l|}{ Trace minerals } \\
\hline Zinc & $20.2^{b}$ & $16.2^{d}$ & $18.2^{C}$ & $24.2^{\mathrm{a}}$ & 0.087 \\
\hline Copper & $2.2^{\mathrm{ab}}$ & $1.9^{c}$ & $2.1^{\mathrm{bc}}$ & $2.4^{\mathrm{a}}$ & 0.068 \\
\hline Manganese & $19.2^{\mathrm{a}}$ & $14.2^{\mathrm{b}}$ & $18.2^{\mathrm{a}}$ & $20.2^{\mathrm{a}}$ & 0.574 \\
\hline Iron & $37.4^{\mathrm{a}}$ & $24.3^{b}$ & $27.3^{\mathrm{b}}$ & $40.3^{a}$ & 0.769 \\
\hline
\end{tabular}

Table 6 Amino acid composition of four sorghum varieties (\% DM) Can AA be hgher than CP?

\begin{tabular}{|c|c|c|c|c|}
\hline & \multicolumn{4}{|c|}{ Sorghum variety } \\
\hline & PAN8625 & PAN8816 & NS5511 & PAN8906 \\
\hline Crude protein & 9.5 & 8.1 & 8.5 & 9.5 \\
\hline Arginine & $2.9^{\mathrm{a}}$ & $2.4^{\mathrm{b}}$ & $2.5^{\mathrm{b}}$ & $3.0^{\mathrm{a}}$ \\
\hline Histidine & 1.6 & 1.3 & 1.3 & 1.4 \\
\hline Isoleucine & $2.9^{\mathrm{a}}$ & $2.1^{\mathrm{c}}$ & $2.6^{\mathrm{b}}$ & $2.8^{\mathrm{a}}$ \\
\hline Leucine & $9.7^{\mathrm{a}}$ & $7.7^{\mathrm{c}}$ & $8.9^{\mathrm{b}}$ & $9.5^{\mathrm{a}}$ \\
\hline Lysine & 1.7 & 1.5 & 1.3 & 1.7 \\
\hline Methionine & 1.1 & 0.8 & 1.0 & 1.1 \\
\hline Phenylalanine & $3.7^{\mathrm{a}}$ & $2.7^{\mathrm{c}}$ & $3.4^{\mathrm{b}}$ & $3.8^{\mathrm{a}}$ \\
\hline Threonine & $2.5^{\mathrm{ab}}$ & $2.2^{\mathrm{c}}$ & $2.3^{\mathrm{bc}}$ & $2.6^{\mathrm{a}}$ \\
\hline Valine & $4.0^{\mathrm{a}}$ & $3.2^{\mathrm{c}}$ & $3.8^{\mathrm{b}}$ & $4.1^{\mathrm{a}}$ \\
\hline Alanine & $6.4^{\mathrm{a}}$ & $5.3^{b}$ & $6.0^{\mathrm{ab}}$ & $6.5^{\mathrm{a}}$ \\
\hline Aspartic acid & $5.2^{\mathrm{a}}$ & $4.2^{\mathrm{c}}$ & $4.5^{\mathrm{bc}}$ & $5.0^{\mathrm{ab}}$ \\
\hline Cysteine & 0.1 & 0.1 & 0.2 & 0.1 \\
\hline Glutamine & $16.6^{\mathrm{a}}$ & $12.3^{\mathrm{c}}$ & $14.1^{\mathrm{b}}$ & $15.2^{\mathrm{ab}}$ \\
\hline Glycine & $2.6^{\mathrm{ab}}$ & $2.3^{\mathrm{b}}$ & $2.4^{\mathrm{ab}}$ & $2.8^{\mathrm{a}}$ \\
\hline Proline & $6.0^{\mathrm{a}}$ & $4.6^{c}$ & $5.4^{\mathrm{b}}$ & $5.8^{\mathrm{a}}$ \\
\hline Serine & 3.3 & 2.9 & 3.1 & 3.4 \\
\hline Tyrosine & $2.9^{\mathrm{a}}$ & $2.2^{c}$ & $2.6^{\mathrm{b}}$ & $2.9^{\mathrm{a}}$ \\
\hline
\end{tabular}

${ }_{a, b, c, d}$ Means in the same row with different superscripts are significantly different $(P<0.05)$. 
The mineral concentrations varied among the four varieties (Table 5). The non-tannin variety, PAN8816, generally had a lower mineral concentration than the other varieties. In the current study PAN8906 and PAN8625 had higher mineral concentration than the other varieties. However, the calcium level obtained in the current study was lower than that reported by Shegro et al. (2012), although Samia et al. (2005) also recorded low values, similar to those in the current study. The highest value for $\mathrm{Na}$, namely $40 \mathrm{mg} / \mathrm{kg} \mathrm{DM}$, in this study is lower than that reported by Awadelkareem et al. (2009) and Shegro et al. (2012), who reported values of $63.0-70.0$ and $58.3-61.8 \mathrm{mg} / \mathrm{kg} \mathrm{DM}$, respectively.

The amino acid composition of the four sorghum varieties varied little among varieties (Table 6). There was no difference $(P>0.05)$ between varieties in the concentration of histidine, lysine, methionine, cysteine or serine. The amino acid digestibility is presented in Table 7. This was generally lower in PAN8625 and NS5511 than in the non-tannin varieties PAN8816 and PAN8906. NS5511, which had high condensed tannin levels, yielded a low amino acid digestibility for arginine, histidine, phenylalanine, threonine and tyrosine. These findings are consistent with the strong negative correlation between tannin content and digestibility recorded by Gous et al. (1982). There was no difference $(P>0.05)$ in gross energy content (Table 8) between varieties.

The ME content differed, with the tannin varieties having lower AME and TME contents than the nontannin ones. Amino acid digestibilities, AME and TME of the tannin varieties were low in the present study. Condensed tannins have been reported to reduce feed intake (Oduhu \& Baker, 2005; Bryden et al., 2009), metabolizable energy (Bryden et al., 2009; Perez-Maldonado \& Rodrigues, 2009; Sannamani et al., 2010; Sedghi et al., 2011) and amino acid digestibility (Selle et al., 2010; Ebadi et al., 2011) in broilers. Such limiting factors are the result of the poor nutritional quality of the protein (kafirins and glutelin) and subsequently attributed to low solubility and deficiencies in amino acids (Sastry et al., 1986; Selle et al., 2010). Therefore, productivity is likely to be reduced when broiler chicks are fed diets containing high concentrations of over $80 \%$ of sorghum to replace maize (Oduhu \& Baker, 2005; Donald et al., 2008), although tannin-free sorghum might reduce productivity because of factors other than tannin content.

Table 7 Amino acid digestibility of grains of four sorghum varieties (\% DM) fed to fasted roosters

\begin{tabular}{|c|c|c|c|c|}
\hline & \multicolumn{4}{|c|}{ Sorghum variety } \\
\hline & PAN8625 & PAN8816 & NS5511 & PAN8906 \\
\hline Arginine & $56.7^{c}$ & $76.3^{b}$ & $34.1^{d}$ & $82.4^{\mathrm{a}}$ \\
\hline Histidine & $86.9^{\mathrm{a}}$ & $87.6^{\mathrm{a}}$ & $37.9^{c}$ & $77.2^{b}$ \\
\hline Isoleucine & $68.5^{b}$ & $68.7^{b}$ & $56.8^{c}$ & $77.7^{\mathrm{a}}$ \\
\hline Leucine & 78.7 & 86.1 & 74.1 & 88.6 \\
\hline Lysine & 78.5 & 79.5 & 66.7 & 77.1 \\
\hline Methionine & 81.9 & 75.6 & 73.3 & 82.9 \\
\hline Phenylalanine & $68.1^{\mathrm{b}}$ & $84.5^{a}$ & $55.7^{c}$ & $80.1^{\mathrm{a}}$ \\
\hline Threonine & 80.5 & 79.4 & 68.7 & 83.2 \\
\hline Valine & 67.9 & 69.8 & 59.4 & 77.9 \\
\hline Alanine & 68.8 & 67.8 & 60.8 & 76.5 \\
\hline Aspartic acid & 81.9 & 81.1 & 76.0 & 83.2 \\
\hline Cysteine & 75.0 & 74.3 & 83.3 & 92.9 \\
\hline Glutamine & 86.3 & 83.9 & 85.7 & 84.9 \\
\hline Glycine & 81.5 & 80.4 & 78.9 & 77.6 \\
\hline Proline & 86.7 & 85.2 & 85.1 & 89.8 \\
\hline Serine & 86.1 & 91.7 & 80.1 & 90.6 \\
\hline Tyrosine & $50.0^{b}$ & $54.4^{b}$ & $29.1^{c}$ & $66.3^{\mathrm{a}}$ \\
\hline Arginine & $56.7^{c}$ & $76.3^{\mathrm{b}}$ & $34.1^{d}$ & $82.4^{\mathrm{a}}$ \\
\hline
\end{tabular}


Table 8 Utilization of energy of four sorghum varieties by roosters

\begin{tabular}{llcc}
\hline $\begin{array}{l}\text { Sorghum } \\
\text { variety }\end{array}$ & GE & AME & TME \\
\hline PAN8625 & $17.6^{\mathrm{a}}$ & $14.0^{\mathrm{c}}$ & $14.4^{\mathrm{b}}$ \\
PAN8816 & $17.5^{\mathrm{b}}$ & $15.1^{\mathrm{a}}$ & $15.1^{\mathrm{a}}$ \\
NS5511 & $17.6^{\mathrm{a}}$ & $13.1^{\mathrm{d}}$ & $13.2^{\mathrm{c}}$ \\
PAN8906 & $17.6^{\mathrm{ab}}$ & $15.0^{\mathrm{b}}$ & $15.4^{\mathrm{a}}$ \\
\hline
\end{tabular}

GE: gross energy (MJ/kg DM);

AME: apparent metabolizable energy (MJ/kg DM);

TME: true metabolizable energy (MJ/kg DM).

a,b,c Means in the same column with different superscripts are significantly different $(P<0.05)$.

\section{Conclusion}

The sorghum varieties NS5511 and PAN8625 contained condensed tannins, while PAN8816 and PAN8906 are non-tannin varieties. There were variations in the nutritional profiles of the four sorghum varieties evaluated in the current study, which could be attributed to factors such as genotype, environment and growing conditions. The tannin sorghum varieties had low amino acid digestibility and metabolizable energy compared with the non-tannin varieties, which suggests the anti-nutritional activity of the tannins. On the other hand, the tannin varieties had higher levels of antioxidants than the non-tannin varieties, thus highlighting their health-promoting potential. It can therefore be concluded that nutrient content and nutritive value should both be considered when selecting sorghum varieties for poultry feeding.

\section{Acknowledgements}

The authors would like to acknowledge the National Research Foundation (NRF) GUN (85101) and AB Vista, UK for their financial support.

\section{References}

Abdel-Rahman, I.E., 2000. Microbiological and biochemical changes during fermentation of sorghum. M.Sc. thesis, University of Khartoum, Sudan.

AOAC, 2005. Official Methods of Analysis, 18th edition. Association of Official Analytical Chemists, Arlington, Virginia, USA.

Awadelkareem, A.M., Muralikrishn, G., El Tinay, A.H. \& Mustafa, A.L., 2009. Characterization of tannin and study of in vitro protein digestibility and mineral profile of Sudan and Indian sorghum cultivars. Pak. J. Nutr. 8, 469-476.

Awika, J.M., Rooney, L.W., Wu, X., Prior, R.L. \& Cisneros-Zevallos, L., 2003. Screening methods to measure antioxidant activity of sorghum (Sorghum bicolor) and sorghum products. J. Agr. Food Chem. 51, 6657-6662.

Awika, J.M., McDonough, C.M. \& Rooney, L.W., 2005. Decorticating sorghum to concentrate healthy phytochemicals. J. Agr. Food Chem. 53, 6230-6234.

Basahy, A., 1995. Chemical composition of sorghum grains (Sorghum bicolor (L.) Moench, Poaccae) grown in Gizan area, Saudi Arabia. J. Sci. Res. 13, 151-161.

Boren, B. \& Waniska, R.D., 1992. Sorghum seed colour as an indicator of tannin content. J. Appl. Poult. Res. $1,117-121$.

Boudries, N., Belhaneche, N., Nadjemi, B., Deroanne, C.,Mathlouthi, M., Roger, B. \& Sindic, M., 2009. Physiochemical and functional properties of starches from sorghum cultivated in the Sahara of Algeria. Carbohydrates Poly. 78, 475-480.

Bryden, W.L., Selle, P.H., Cadogan, D.J., Li, X., Muller, N.D., Jordan, D.R., Gidley, M.J. \& Hamilton, W.D., 2009. A review on the nutritive value of sorghum in broilers. Rural Industry Research and Development Corporation, Kingston, Australia.

Chiremba, C., Taylor, J.R.N. \& Duodu, K.G., 2009. Phenolic content, antioxidant activity, and consumer acceptability of sorghum cookies. Cer. Chem. 86, 590-594.

Donald, V.T. \& Ravindran, V., 2008. Effect of cereal type on the performance, gastrointestinal tract development and intestinal morphology of newly hatched broiler chicks. J. Poult. Sci. 45, 45-50.

Dykes, L., Rooney, L.W., Waniska, R.D. \& Rooney, W.L., 2005. Phenolic compounds and antioxidant activity of sorghum grains of varying genotypes. J. Agr. Food Chem. 53, 6813-6818. 
Ebadi, M.R., Sedghi, M., Golian, A. \& Ahmadi, H., 2011. Prediction of the true digestible amino acid contents from the chemical composition of sorghum grain for poultry. Poult. Sci. 90, 2397-2401.

Gassem, M.A.A. \& Osman, A.M., 2003. Proximate composition and the content of sugars, amino acids and anti-nutritional factors of three sorghum varieties. Agricultural Research Center, King Saud University, Research Bulletin No 125, 5-19.

Geleta, N., Labuschagne, M.T., Osthoff, G., Hugo, A. \& Bothma, C., 2005. Physical and chemical properties associated with food quality in sorghum. S. Afr. J. Plant Soil 22, 175-179.

Gous, R.M., Kuyper, M.A. \& Dennison, C., 1982. The relationship between tannic acid content and metabolizable energy concentration of some sorghum cultivars. S. Afr. J. Anim. Sci. 12, 39-45.

Issa, S., 2009. Nutritional value of sorghum for poultry feed in West Africa. PhD thesis, Kansas State University, Manhattan, Kansas, USA.

Mabelebele, M. \& Iji, P.A., 2013. The health benefits of sorghum grains for poultry and pigs. In: Sorghum: Production, Growth Habits and Health Benefits. Ed: Parra, P.C., Nova Science Publishers, NY, USA, Chapter 3, 63-81.

McNab, J.M. \& Blair, J.C., 1988. Modified assay for true and apparent metabolizable energy based on tube feeding. Br. Poult. Sci. 29, 697-707.

Medugu, C.I., Kweri, I.D., Igwebuiken, J., Nkama, I., Mohammed, I.D. \& Hamaker, B., 2010. Carcass and blood components of broiler chickens fed sorghum or millet as replacement for maize in the semi-arid zone of Nigeria. Agri. Biol. J. North Am. 1, 326-329.

Neucere, N.J. \& Sumrell, G., 1980. Chemical composition of different varieties of grain sorghum. J. Agri. Food Chem. 28, 19-21.

Nyachoti, C.M., Atkinson, J.L. \& Leeson, S., 1997. Sorghum tannins: a review. Wrld Poult. Sci. J. 53, 5-21.

Oduhu, G.W. \& Baker, D.H., 2005. Some tropical high tannin sorghums and their effects on broiler performance. Agricultura Tropica et Subtropica 38, 105-110.

Parnian, F., Taghizadeh, A. \& Nobari, B.B., 2013. Use of in vitro gas production technique to evaluate the effects of microwave irradiation on sorghum (Sorghum bicolor) and wheat (Triticum sp.) nutritive values and fermentation characteristics. J. Boisci. Biotech. 2, 125-130.

Perez-Maldonado, R.A. \& Rodrigues, H.D., 2009. Nutritional characteristics of sorghums from Queensland and New South Wales for chicken meat production [RIRDC Publication, 07] Barton: Rural Industries Research and Development Corporation.

Price, M.L., Van Scoyoc, S. \& Butler, L.G., 1978. A critical evaluation of the vanillin reaction as an assay for tannin in sorghum grain. J. Agr. Food Chem. 26, 1214-1218.

Ragaee, S., Abdel-Aal, E.M. \& Noaman, M., 2006. Antioxidant activity and nutrient composition of selected cereals for food use. Food Chem. 98, 32-38.

Rooney, L.W. \& Serna-Saldvar, S.O., 2000. Sorghum. Handbook of Cereal Science and Technology. (2nd ed.). Eds: Kulp, K. \& Ponte, J., New York, NY. pp. 149-175.

Samia, M.A., Hagir, B.E., Wisal, I.H., Elfadi, I.E.B. \& Abdullahi, H.E., 2005. Proximate composition, antinutritional factors and mineral content and availability of selected legumes and cereals grown in Sudan. J. Food Technol. 3, 511-515.

Sannamani, P., Tyagi, P.K., Tyagi, P.K., Sastry, V.R.B., Elangovan, A.V. \& Mandal, A.B., 2010. The value of high and low tannin sorghum as broiler feed. Ind. J. Poult. Sci. 45, 35-41.

SAS, 2008. Statistical Analysis Systems User's Guide: version 9.2. $2^{\text {nd }}$ ed. SAS Institute Inc., North Caroline, USA.

Sastry, L.V.S., Paulis, J.W., Bietz, J.A. \& Wall, J.S., 1986. Genetic variation of storage proteins in sorghum grain: Studies by isoelectric focusing and high-performance liquid chromatography. Cer. Chem. 63, 420-427.

Sedghi, M., Ebadi, M.R., Golian, A. \& Ahmadi, H., 2011. Estimation and modelling true metabolisable energy of sorghum grain for poultry. Poult. Sci. 90, 1138-1143.

Selle, P.H., Gill, R.J. \& Downing, J.A., 2010. The vulnerability of sorghum to 'moist-heat'. Proceedings Australian Poultry Science Symposium 21, 68-71.

Shegro, A., Nemera, G.S., Van Biljon, A. \& Labuschagne, M.T., 2012. Diversity in starch, protein and mineral of sorghum landrace accessions from Ethiopia. J. Crop Sci. Biotech. 15, 275-280.

Singleton, V.L. \& Rossi, J.A., 1965. Colorimetry of total phenolics with phosphomolybdic-phosphotungstic acid reagents. Am. J. Enol. Vit. 16, 144-158.

Taylor, J.R.N. \& Dewar, J., 2001. Developments in sorghum food technologies. Adv. Food. Nutr. Res. 43, 217-264.

Van Soest, P.J., Robertson, J.B. \& Lewis, B.A., 1991. Methods for dietary fiber, neutral detergent fiber and non-starch polysaccharides in ration to animal nutrition. J. Anim. Sci. 74, 3583-3597. 